\title{
Curriculum Studies in Health and Physical Education
}

\section{School PE and 'fat' kids: maintaining the rage and keeping a sense of perspective}

\section{Richard Tinning}

To cite this article: Richard Tinning (2020): School PE and 'fat' kids: maintaining the rage and keeping a sense of perspective, Curriculum Studies in Health and Physical Education, DOI: 10.1080/25742981.2020.1773883

To link to this article: https://doi.org/10.1080/25742981.2020.1773883

曲 Published online: 04 Jun 2020.

Submit your article to this journal $\asymp$

Џll Article views: 3

Q View related articles $๘$

View Crossmark data 


\title{
School PE and 'fat' kids: maintaining the rage and keeping a sense of perspective
}

\author{
Richard Tinning ${ }^{\mathrm{a}, \mathrm{b}}$ \\ ${ }^{\mathrm{a} S}$ School of Human Movement \& Nutrition Science, University of Queensland, Brisbane, Australia; ${ }^{\mathrm{b}}$ Dalarna \\ University, Falun, Sweden
}

\begin{abstract}
This paper is about 'fat' kids in HPE classes. The motivation for this paper comes as a personal response to my reading of Roxane Gay's book Hunger: A Memoir of (My) Body. Hunger is thoughtful, passionate, articulate, sad and overall troubling. It also raised questions for me about whether health and physical education (HPE) is a safe space for fat young people and whether or not there is any possibility that HPE might be a transformative space that some scholars suggest. It raises issues regarding curriculum choice and pedagogy, but also about dispositional change such that all HPE teachers become more sensitive to the needs, feelings and capacities of young fat kids.
\end{abstract}

\section{KEYWORDS}

HPE; critical pedagogy; fat pedagogy; obesity

This paper is about ' $\mathrm{fat}^{\text {' }}$ kids in HPE classes. The motivation for this paper comes as a personal response to my reading of Roxane Gay's book Hunger: A Memoir of (My) Body. Hunger is thoughtful, passionate, articulate, sad and overall troubling. It also raised questions for me about whether health and physical education (HPE) is a safe space for fat young people and whether or not there is any possibility that HPE might be a transformative space that scholars such as Cameron, Norman, and Petherick (2017) suggest it could become.

Roxane Gay is a woman who is ethnic/black/middle-class/obese/Catholic and with fluid sexuality. Those characteristics/labels, dispositions or traits she brought with her to school $\mathrm{PE} /$ sport classes when she was young. Responding adequately to her needs, and those like her, will not be easy for HPE teachers.

\section{Hunger: A Memoir of (My) Body}

For those not familiar with Gay's work, she is a Haitian/American feminist, author, and academic who wrote, among other works, the New York Times bestseller Bad Feminist. In Hunger, Gay tells of her constant struggle with her weight. At her heaviest, she was about 260 kilograms.

Hunger is Gay's journey from a bright, active, playful, 'good little catholic girl', to obese teenager, to 'fat camp', to weight loss clinics, to an adult who continues to wrestle with the 
tensions to consume and abstain and to rage over the ways in which she herself, and the public at large, 'see' the obese body.

Gay says she hates herself. Or more accurately, she hates her body.

I hate my weakness at being unable to control my body. I hate how I feel in my body. I hate how people see my body. I hate how people stare at my body, treat my body, comment on my body. I hate equating my self-worth with the state of my body and how difficult it is to overcome this equation. (p. 135)

She is shamed by her body, '... shamed at how I look, ashamed of my weakness, the shame of knowing it is in my power to change my body and yet, year after year, not changing it' (p. 171). Yet she does try-

I eat right. I work out. My body becomes smaller and starts to feel more like mine and not a cage of flesh I carry with me. That's when I feel a new kind of panic because I am seen in a different way.

... That version of myself is terrifying and may be even beautiful, so I panic, and within a few weeks, I undo all the progress I've made. I stop going to the gym. I stop eating right. I do this until I feel safe again. (p. 171)

\section{She also laments that}

Regardless of what you do, your body is the subject of public discourse with family, friends and strangers alike. This commentary is often couched as concern, as people only having your best interests at heart [I wonder if this is what we in HPE do]. You are your body, nothing more, and your body should damn well become less. (p. 110)

We learn that, as an adult, Gay does not suffer from ignorance where exercise is concerned. Rather, she says suffers from 'inertia' (p. 148).

I generally dread exercise, all of it, and then I feel terrible about myself for being lazy, unmotivated, utterly lacking in discipline or self-regard, because intellectually, I know exercise is good for me. My hatred of exercise is unfortunate because I know exercise is necessary for the human body. It is a key component of losing weight and good health. I know the math. (p. 147)

Although not athletic herself, Gay has many athletic friends and they report on their athletic achievements via social media. 'The pictures accompanying these updates reveal people glowing with health and vigor' ( $p$.154). While she says that they should be rightly proud of their achievements, she gets ' ... angry as I see these updates because these people are doing things I cannot.' She also says she is ' ... seething with jealousy. I want to be part of the active world. I want it so very badly' (p. 155).

Gay does not specifically mention school PE. But she does say that ' $i \mathrm{i}] \mathrm{n}$ school, we played dodgeball and tetherball. We did the Presidential Fitness challenge and I finished the running portion last nearly every year'. Moreover, '[i]n high school, sports were a significant and mandatory part of the curriculum, which was not ideal for me' (p. 72).

As a result of her participation in school sports, Gay concluded that she was 'allergic to sports'. The affect of sports (aka) PE for Gay was certainly not positive. It was hardly affirming of a love for movement and physical activity. However, motivated by her selfclaimed knowledge of the benefits of exercise in regards to healthy living and body weight, she continued, as an adult, to go to the gym to workout. 
This is a compelling and terribly sad narrative, but the impact of Gay's story becomes even more troubling when we learn that her journey into fatness was the result of a deep psychological trauma induced by sexual abuse.

When I was twelve years old I was raped and then I ate and ate to build my body into a fortress. I was a mess and then I grew up and away from that terrible day and became a different kind of mess - a woman doing the best she can do to love well and be loved well. To live and be human and good. (p. 276)

The emotion Gay's story stirred in me was rage. Rage at perpetrators of the abuse, then rage at the treatment she suffered under the not so invisible prejudices of fat bias and the cult of the body.

\section{Maintaining the rage}

In 1975 when Gough Whitlam, the then Prime Minister of Australia, was 'dismissed' by the Governor-General, he stood on the steps of parliament house and urged his followers to 'maintain the rage'. As a critical scholar, I have maintained the rage against injustice, social inequities and oppression across my career. But although I am often enraged, more often I am just troubled. Both emotions require thoughtful response and action.

When I think of the violence done to young Roxane Gay, I am enraged.

When I think of her in PE class I am troubled.

When I think of the rise of the 'far-right' that was manifest in the election of Donald Trump, I am considerably troubled.

When I think of the powerful corporate pedagogues who try to shape the minds of young people for commercial interests that are often in direct conflict or tension with the messages regarding body image and sexuality in the HPE curriculum, I am troubled.

I am troubled by the fact that too many kids still find PE boring, alienating and downright embarrassing.

I am troubled by the fact that there are still some HPE teachers who seem unaware that some of their practices reinforce fat-biased, gendered, sexist, homophobic, or racial attitudes.

Depending on the issue, I continue to shift between being troubled and being enraged. Overall I maintain what I consider to be a 'quiet rage.' Others can, and do, rage louder. The voice of rage against injustice from the perspective and position of the disempowered, the disenfranchised, and the marginalised was clearly evident in 2019 when the world witnessed Greta Thunberg's determined protest on the steps of the Swedish parliament. This young student wanted to draw attention to climate change and the intransigence of politicians to do something about it. Her protest went viral and soon thousands of students from other countries joined her in the protest.

Greta's voice of rage against injustice is what Plato called thymos (Carlson, 1998) and the ethic of this voice underpins the very foundations of the critical project in all its manifestations. Elsewhere (Tinning, 2002; Tinning, Philpot, \& Cameron, 2016) I have advocated that our field uses all three rhetorical styles that form the basis of Plato's dialogues (see Carlson, 1998) as a way to engage rage with reason, personal stories with collective narratives, and emotion with objectivity. Using all three discourses can enable something of a dialectic between people's lived world and the disinterested discourse of health science within a critical theoretical framework. 
In regard to fatness, in the field of HPE, and of Human Movement Studies or Exercise Science more broadly, it is the analytic voice of logos, characterised by reason, critique, and the 'truth games' of science and philosophy that dominate. This rhetorical voice is not only used in the representation of obesity as a serious medical issue (see for example Seidell, 2000), but also in challenges to the very idea of the obesity crisis (see Gard \& Wright, 2005). Such is the dominance of logos in HPE that we tend to hear little of the voice of thymos.

However, neither rage nor reason will necessarily create the conditions for more sensitive and 'healthy' experiences for fat young people in HPE. In prosecuting the mission of making HPE an enjoyable experience for fat kids we need to hear their voices and also the voices of those who previously experienced PE as fat kids. 'Although policy, conversation and practice are often about fatness, what is largely missing are the voices of fat people' (Pausé, 2019, p. 663).

Advocacy for the personal voice of story telling, cultural mythology, autobiography, and literature (the voice of mythos) has been a key feature of the rise of narrative inquiry in our field (see Dowling \& Garrett, 2017) over the past three decades and we need to see more of it on the reading lists of our PETE and HMS degree programs. One such narrative is provided by Fat Studies scholar Pausé (2019).

Pausé, like some other Fat Studies scholars, claims back the word 'fat' and self-identifies as fat. In her autobiographical paper, '(Can we) get together?: Fat kids and physical education' (2019), Pausé offers her experiences of physical activity, PE and exercise as a fat kid growing up in the USA. Her story describes experiences that are similar to those of Gay and many other fat people (see Rice, 2007).

Pausé enjoyed movement and physical activity as a child, but that changed when she went to school and began compulsory classes in PE.

I lost my love of movement, thanks to uniforms that did not fit, activities that had not been modified for my body, taunting from my peers and the anti-fat bias of my teachers. The end result was a hostile environment that removed the joy associated with movement and exercise for me. (p. 662)

Pausé goes on to reveal that in secondary school the

... most dreaded hour of the day is PE. I hate having to undress in front of my classmates; I hear them making fun of my fat body ... My enjoyment for playing has been muted, as I often struggle to complete the tasks set forward by the teacher. (p. 665)

She also explains how much she loathes running and in particular the Presidential Fitness Test (the same test that Gay found egregious).

It never occurred to Pausé to ask for simple modifications or other kinds of exercises that might have been more suitable for her body shape. Tellingly she says that ' $\mathrm{I}] \mathrm{t}$ is likely my teacher would not have been able to provide these kinds of the modification even had I requested them' (p. 667). Of course, it shouldn't have been her responsibility to have to ask in the first place, but it does raise the issue of whether or not HPE teachers have sufficient pedagogical content knowledge to respond to such a question.

Notwithstanding her negative school PE experiences, as an adult in graduate school, Pausé returned to exercise apparently to keep the interest of her male romantic partner. She says that in grad school she began to 'wage another war against myself. Her exercise 
regime went from working out privately on a home treadmill to joining a gym and participating in group fitness classes. Over time, her commitment to her exercise regime became obsessive ' I found myself adding on additional classes, doing at least two a day, if not three' (p. 666). We don't learn what broke this pattern of exercise, but she does say that, at the time of writing, she is '... currently not physically active' (p. 663).

As with Gay, in Pausé's story, we find a very intelligent young woman who becomes, in some complicated way, complicit in her own subjugation to exercise. Offering an analysis of the underlying causes of this subjugation is beyond the scope of this paper (and the expertise of this author), but both stories provide vivid accounts of how PE affects fat kids. Roxane Gay's story, in particular, is a powerful combination of the voices of both mythos and thymos. It's autobiographical and it's a rage against injustice. It taps into our emotions and helps us better understand something of the life-world of obese people, both in our PE classes and beyond the school gate. It does not, however, offer any hints as to how HPE might help.

Cat Pausé's story is both mythos and logos. She uses her own story as first-hand evidence of the negative affect of PE on her like a fat kid (mythos) to provide a rationale (logos) for her advocacy of 'fat pedagogy'. According to Pausé (2019)

A fat pedagogy rejects the language framing the 'obesity epidemic' ... and allows for a reconsideration of what we know about fatness, equity, health and well-being. Within physical education spaces, a fat pedagogy would not put kids to the side because they are unable to complete an activity. Instead, it would seek to find activities suitable for fat bodies and use those instead. (p. 667)

\section{Moving beyond critique}

I have long been troubled by the fact that HPE is complicit in what I once called the cult of slenderness (Tinning, 1985), what Lupton (1995) more accurately called the cult of the body. HPE explicitly and implicitly reinforces a particular relationship between health and body shape/size. This relationship, as numerous scholars have argued (e.g. Wright \& Welch, 2011), is a manifestation of the ideology of healthism which fuels narratives about obesity as solely the result of personal irresponsibility and lack of willpower.

There is abundant good scholarship in HPE that specifically sets out to challenge these ideologies and to offer transformative possibilities for fat young people (for example see Garrett, 2004; Greenleaf, Martin, \& Rhea, 2008; Tinning et al., 2016). However, as Cameron and Watkins (2018) argue, although critical educational scholarship has done a good job of identifying the social injustices occurring with regard to gender, race, class, sexuality, and ability, less educational scholarship has focused on educational and pedagogical interventions to reduce weight-based oppression.

Certainly, a critical pedagogy [for HPE] should aim 'to promote safe leaning spaces for all students, regardless of size, and to disrupt weight-related oppression, intolerance, insensitivity, and discrimination' (Cameron, 2014, p. 221). However, as

Fitzpatrick (2013) notes, ' ... academic discourses that encourage critical approaches ... often fail to provide concrete examples of critical practice' (p. 208). Accordingly, we need to ask what specific things can be done to make '... PE classes ... transformative learning sites to empower young people in their negotiation of [body] messages' (Azzarito, 2016, p. 20). 
The 'body curriculum' work of Oliver and Lalik (2001) and Azzarito and Solomon (2009) and the fat-activist work of Cameron (2015a), are responses to this challenge.

However, exemplary though these programs are, I am left thinking that for some students their relationship to physical activity and bodies is rather more complicated than can be understood simply by targeting the ideologies of healthism and the cult of the body.

For instance, Roxane Gay is smart, she has a well-developed feminist critique, and she is media savvy. She probably would have done well in the body curriculum classes that Oliver and Lalik (2001) describe. She knows all about representation and the media. In regard to The Biggest Loser, which she watched avidly for the first few sessions, she writes:

The Biggest Loser is an unholy union of capitalism and the weight-loss industrial complex. On the surface, The Biggest Loser is a television show about weight loss, but really it's anti-obesity propaganda, offering wish fulfillment for people with unruly, overweight bodies, both on the show and in the viewing audience (p. 116).

"This is not a show about people becoming empowered through fitness ... "It is a show" ... about fat as an enemy that must be destroyed, a contagion that must be eradicated." (p. 117)

Notwithstanding her insightful critique of this show reality TV show, Gay admits that " ... some part of me still yearns for the salvation they promise' (p. 122). Even for someone as smart as Gay, the rational, cognitive critique is, to some extent at least, in some tension with her emotional self and her psyche. I wonder if 'salvation' is what HPE purports to offer the fat child?

Maybe a 'body curriculum' (Oliver \& Lalik, 2001) approach would have helped Gay's classmates understand body-size discrimination and fat-phobia. And maybe that would have helped her in some way. But, developing and implementing a 'body curriculum' in the first instance requires that HPE teachers themselves recognise body-size discrimination and fat-phobia as 'an issue' that requires a targeted pedagogical approach (see Greenleaf et al., 2008; Wright \& Welch, 2011).

\section{Realistic expectations: do no harm}

Obviously HPE can't be responsible for healing young people with histories of trauma, but surely it should cause no further harm. It seems to me that for HPE to at least do no harm to obese students like Gay and Pausé, teachers need to place sensitivity, understanding, compassion, and a non-judgmental attitude above BMIs, sports techniques, and fitness testing.

When HPE is conceived as a vehicle for weight management and a key site in the fight against obesity, it is no wonder that fat kids enter HPE class as the alienated other. Pausé (2019) imagines a different HPE space

... where fat kids could learn new ways to move their fat bodies without shame, or ridicule, of chafing; spaces where fat kids could use their size to their advantage, when appropriate, in sports situations and learn modifications for other activities when necessary; spaces where fat kids are not left out, left behind or left feeling less worthy because of their fatness. (p. 667)

In this regard Cameron and Watkins (2018) suggest ' ... there is an urgent need to identify curricular examples and pedagogical approaches that serve to improve the experiences of fat students ...' (p. 1). One pedagogical approach that is advocated to improve the experiences of fat students and create Pausé's imaginary (safe) HPE space is 'fat pedagogy'. 
These sentiments were the catalyst for a special issue of the journal Fat Studies (2018, vol 7, \# 1) devoted fat pedagogy. In the issue we find articles devoted to storying fat pedagogy, practicing fat pedagogy, researching fat pedagogy, and expanding fat pedagogy. We read about the experience of teaching health psychology from a size acceptance perspective (Chrisler, 2018b), and of the experience of integrating fat pedagogy into an apparel design course, a field that has long adhered to the thin ideal (Chrisler, 2018a). Interesting though these articles are, they don't speak specifically to our field. Within the scope of our field is an article by Ebbeck and Austin (2018) that describes a programme to disrupt fat oppression, framing fitness centres as the classroom and personal trainers as the teachers. Alas there are no articles that deal with fat pedagogy in HPE classes.

Helping prospective HPE teachers acquire the necessary skills and knowledge to operationalise Pausé's (2019) vision is a challenging task. To begin, (H)PETE programmes would need to engage student teachers with different content knowledge about fatness (using the voices of mythos, thymos and logos). Cameron's (2015b) paper 'Teaching resources for postsecondary educators who challenge dominant 'obesity' discourse' provides and excellent 'go to' resource in this regard. Providing different pedagogical content knowledge (e.g. how to adapt activities to suit the capacities of fat kids) would also be a necessary.

The hardest thing, the most challenging task, would be to bring about dispositional change such that HPE teachers become more sensitive to the needs, feelings and capacities of young fat kids. Unfortunately, we know that many HPE teachers have an anti-fat bias (see Greenleaf \& Weiller, 2005) and consider that a primary role of HPE is to help combat obesity (see Greenleaf et al., 2008). Just as troubling is the finding that not only are such attitudes prevalent in pre-service teachers (O’Brien, Hunter, \& Banks, 2007), there is also evidence that ' $\ldots$ our HPE teacher training programmes may directly foster stronger antifat biases and negative beliefs regarding obese children instead of developing inclusive and bias-free attitudes among future schoolteachers' (Lynagh, Cliff, \& Morgan, 2015, p. 601).

Of course, there are teachers who do not fit the stereotype. Moreover, in Australia and New Zealand for example, HPE curricula have introduced a socio-critical perspective that enables teachers to foreground social justice and to challenge oppressive ideas and practices such as anti-fat bias in their curriculum practice. But since these teachers still work in a broader environment in which ' ... the "obesity epidemic" lens [now] frames how almost everyone thinks about fatness, health and activity' (Evans, Rich, \& Davies, 2004), optimism for change needs to be tempered. Changing the attitudes of individual teachers is not the necessary and sufficient condition to change the experience of fat kids in HPE. Here I agree with Sykes and McPhail (2008) when they argue, ' $t$ ] he change we encourage goes beyond the attitudes of individual teachers or administrators ... fat phobia is a society-wide problem' (p. 91).

In the face of widespread societal fat phobia and the pernicious influence of the cult of the body, maintaining the rage and voicing that rage while working with the principles of fat pedagogy and critical obesity pedagogy to develop what Roxanne Gay calls 'body positivity' (Gay, 2017) seems all we can realistically do within HPE.

\section{Note}

1. I am intentionally using the term 'fat' rather than the medicalised term 'obesity'. I will, however, use the term obesity at times when it has been used by others, including Roxane Gay herself, to describe their body. 


\section{Disclosure statement}

No potential conflict of interest was reported by the author(s).

\section{Notes on contributors}

Richard Tinning is Emeritus Professor in the School of Human Movement \& Nutrition Science at the University of Queensland, Australia. He is also Guest Professor of Educational Science and Sport Pedagogy at Dalarna University, Sweden. Richard was an early advocate of critical pedagogy and has published extensively on school physical education, teacher education and on issues of knowledge and the body in human movement studies. In 2010 he was co-winner of the AIESEP/ IOC President's prize for his significant scholarly contribution to physical education and sport research.

\section{References}

Azzarito, L. (2016). "I guess people are more attracted to white people than black people": Shedding light on racial prejudice, misrepresentation, and (in)visibility of ethnic minority bodies. In D. Robinson, \& L. Randall (Eds.), Social justice in physical education (pp. 15-36). Toronto: Canadian Scholars' Press.

Azzarito, L., \& Solomon, M. (2009). An investigation of students' embodied discourses in physical education: A gendered project. Journal of Teaching in Physical Education, 28(2), 173-191.

Cameron, E. (2014). Throwing their weight around: A critical examination of faculty experiences with challenging dominant obesity discourse in postsecondary education [Doctoral dissertation, Lakehead University].

Cameron, E. (2015a). Toward a fat pedagogy: A study of pedagogical approaches aimed at challenging obesity discourses in post-secondary education. Fat Studies, 4(1), 28-45.

Cameron, E. (2015b). Teaching resources for post-secondary educators who challenge dominant "obesity" discourse. Fat Studies, 4(2), 212-226.

Cameron, E., Norman, M., \& Petherick, L. (2017). Shifting stories of size: Critical obesity scholarship as transformative pedagogy for disrupting weight-based oppression in physical education. In C. Ennis (Ed.), Routledge handbook of physical education pedagogy (pp. 343-355). New York: Routledge.

Cameron, E., \& Watkins, P. (2018). Fat pedagogy: Improving teaching and learning for every body. Fat Studies, 7(1), 1-10.

Carlson, D. (1998). Finding a voice, and losing our way? Educational Theory, 48(4), 541-554.

Chrisler, D. (2018a). Fat fashion: Fattening pedagogy in apparel design. Fat Studies, 7(1), 44-55.

Chrisler, J. (2018b). Teaching health psychology from a size-acceptance perspective. Fat Studies, 7 (1), 33-43.

Dowling, F., \& Garrett, R. (2017). The transformative possibilities of narrative inquiry. In C. Ennis (Ed.), Routledge handbook of physical education pedagogies (pp. 332-343). New York: Routledge.

Ebbeck, V., \& Austin, S. (2018). Burning off the fat oppression: Self-compassion exercises for personal trainers. Fat Studies, 7(1), 81-92.

Evans, J., Rich, E., \& Davies, B. (2004). The emperor's new clothes: Fat, thin, and overweight. The social fabrication of risk and ill-health. Journal of Teaching in Physical Education, 23, 372-391.

Fitzpatrick, K. (2013). Critical pedagogy, physical education and Urban Schooling. New York: Peter Lang.

Gard, M., \& Wright, J. (2005). The obesity epidemic: Science, Morality and ideology. New York, NY: Routledge.

Garrett, R. (2004). Negotiating a physical identity. Sport, Education \& Society, 9(2), 223-237.

Gay, R. (2017). Hunger: A Memoir of (my)body. London: Corsair.

Greenleaf, C., Martin, S., \& Rhea, D. (2008). Fighting fat: How do fat stereotypes influence beliefs about physical education? Obesity, 16(2), 53-59. 
Greenleaf, C., \& Weiller, K. (2005). Perceptions of youth obesity among physical educators. Social Psychology of Education, 8(4), 407-423.

Lupton, D. (1995). The imperative of health: Public health and the regulated body. London: Sage.

Lynagh, L., Cliff, K., \& Morgan, P. (2015). Attitudes and beliefs of non-specialist and specialist trainee health and physical education teachers toward obese children: Evidence for "anti-fat" bias. Journal of School Health, 85, 595-603.

O’Brien, K., Hunter, K., \& Banks, M. (2007). Implicit anti-fat bias in physical educators: Physical attributes, ideology and socialization. International Journal of Obesity, 31(2), 308-314.

Oliver, K., \& Lalik, R. (2001). The body as curriculum: Learning with adolescent girls. Journal of Curriculum Studies, 33(3), 303-333.

Pausé, C. (2019). (Can we) get together? Fat kids and physical education. Health Education Journal, $78(6), 662-669$.

Rice, C. (2007). Becoming "the fat girl": Acquisition of an unfit identity. Women's Studies International Forum, 30, 158-174.

Seidell, J. (2000). The Current obesity epidemic. In C. Bouchard (Ed.), Physical activity and obesity (pp. 21-30). Champaign, IL: Human Kinetics.

Sykes, H., \& McPhail, D. (2008). Unbearable lessons: Contesting fat phobia in physical education. Sociology of Sport Journal, 25, 66-96.

Tinning, R. (1985). Physical education and the cult of slenderness: A critique. ACHPER National Journal, 107(autumn), 10-14.

Tinning, R. (2002). Towards a 'modest' pedagogy: Reflections on the problematics of critical pedagogy. Quest (grand Rapids, Mich ), 54(3), 224-241.

Tinning, R., Philpot, R., \& Cameron, E. (2016). Critical pedagogy, physical education, and obesity discourse: More advocacy than pedagogy. In D. Robinson, \& L. Randall (Eds.), Social justice in physical education: Critical reflections and pedagogies for change (pp. 297-322). Toronto: Canadian Scholars' Press.

Wright, J., \& Welch, R. (2011). Tracing discourses of health and the body: Exploring pre-service teachers' construction of 'healthy" bodies'. Asia-Pacific Journal of Teacher Education, 39(3), 121. 